\title{
Evaluation of the suitability of a partially defatted black soldier fly (Hermetia illucens L.) larvae meal as ingredient for rainbow trout (Oncorhynchus mykiss Walbaum) diets
}

M. Renna ${ }^{1}$, A. Schiavone ${ }^{2,3}$, F. Gai ${ }^{3}$, S. Dabbou², C. Lussiana' ${ }^{1}$, V. Malfatto ${ }^{1}$, M. Prearo ${ }^{4}$, M. T. Capucchio ${ }^{2}$, I. Biasato ${ }^{2}$, E. Biasibetti ${ }^{2}$, M. De Marco ${ }^{2}$, A. Brugiapaglia', I. Zoccarato ${ }^{1}$ and L. Gasco ${ }^{1,3}$

\begin{abstract}
Background: Two trials were performed to evaluate a partially defatted Hermetia illucens (HI) larvae meal as potential feed ingredient in rainbow trout (Oncorhynchus mykiss Walbaum) diets. In the first trial, 360 trout (178.9 $\pm 9.8 \mathrm{~g}$ of mean initial body weight) were randomly divided into three experimental groups ( 4 tanks/treatment, 30 fish/tank). The fish were fed for 78 days with isonitrogenous, isolipidic and isoenergetic diets containing increasing levels of $\mathrm{HI}$, on as fed basis: $0 \%$ (HIO, control diet), 25\% (HI25) and 50\% (HI50) of fish meal substitution, corresponding to dietary inclusion levels of $0,20 \%$ and $40 \%$. In the second trial, 36 trout (4 tanks/treatment, 3 fish/tank) were used to evaluate the in vivo apparent digestibility coefficients (ADC) of the same diets used in the first trial.

Results: Survival, growth performance, condition factor, somatic indexes, and dorsal fillet physical quality parameters were not affected by diet. The highest dietary inclusion of HI larvae meal increased dry matter and ether extract contents of trout dorsal fillet. The use of $\mathrm{HI}$ larvae meal induced a decrease of valuable polyunsaturated fatty acids (PUFA) even if differences were only reported at the highest level of $\mathrm{HI}$ inclusion. The insect meal worsened the lipids health indexes of the same muscle. Dietary inclusion of insect meal did not alter the villus height of the fish. No differences were found among treatments in relation to ADC of ether extract and gross energy, while ADC of dry matter and crude protein were higher in HI25 if compared to HI50.

Conclusions: The obtained results showed that a partially defatted $\mathrm{HI}$ larvae meal can be used as feed ingredient in trout diets up to $40 \%$ of inclusion level without impacting survival, growth performance, condition factor, somatic indexes, dorsal fillet physical quality parameters, and intestinal morphology of the fish. However, further investigations on specific feeding strategies and diet formulations are needed to limit the observed negative effects of the insect meal on the FA composition of dorsal muscle.
\end{abstract}

Keywords: Animal performance, Apparent digestibility coefficient, Carnivorous fish, Fatty acids, Fishmeal substitution, Insect meal

\footnotetext{
* Correspondence: francesco.gai@ispa.cnr.it

${ }^{3}$ Institute of Science of Food Production, National Research Council, Largo P.

Braccini 2, 10095 Grugliasco, TO, Italy

Full list of author information is available at the end of the article
} 


\section{Background}

In the period 2000-2012 the world food fish aquaculture production expanded at a rate of $6.2 \%$ per year [1]. This trend is expected to continue as the demand for fish products will increase, following the raise of the world population expected by 2050. Fishmeal (FM) is considered as the optimal protein source in fish feeds. However, the availability of wild harvested marine fish stocks for FM production is decreasing and conventionally used proteins have been claimed to be no longer sustainable from both economic and ecologic points of view [1]. For these reasons, research has actively worked to deliver fish feed formulations containing alternative protein sources. The most commonly used ones are plant protein sources (such as oilseed meals, cereal proteins and grain legumes) and Processed Animal Proteins (PAPs) derived from animal by-products (poultry meal, hydrolyzed poultry feathers, blood meal). As far as the former are concerned, some adverse effects on performances or intestinal integrity have been reported [2,3] even if technological advances in plant raw material processing and the increased knowledge on fish requirements have allowed the formulation of fish feeds mainly based on plant proteins [3]. PAPs provide good quantities of essential amino acids even if methionine, lysine, histidine, isoleucine and tryptophan could be limiting depending on the drying or cooking methodologies followed during manufacturing [4].

Among PAPs, interest is recently turned to insect meals as they are considered promising and sustainable protein [5, 6] or lipid [7] sources for monogastric animals feeds. In a context of resource scarcity and population growth, insect meals could represent a precious alternative to FM in aquaculture feeds [6], also considering that freshwater carnivorous fish eat insects in their natural environment.

Interesting results have already been reported using insect meals as FM substitute in the diets of some fish species [8-13]. Investigations have also been performed as far as sensory aspects $[9,14]$ and consumer acceptance are concerned [15] with promising results. Nevertheless, potential hurdles have also been highlighted (toxicity of insects through bioaccumulation, deficiencies in amino acids (AA) or long chain fatty acids (FA), chitin content, palatability, digestibility) [6]. To date, the price of insect meals is not yet competitive due to low produced quantities [16]. However, as on December 2016 the EU Commission approved the use of PAPs derived from insect in aquaculture feeds, a huge development of this market is expected in next years. Insects often accumulate fat, especially during their immature stages [6]. Full-fat insect meals contain high amounts of lipids, which are difficult to be managed by the feed industry due to overmuch energy, proneness to oxidation and a decrease in pellet stability [6]. These characteristics can therefore limit the use of insect meals, as replacement of FM, in aquafeeds. Defatting insect meals can be a solution to provide high insect protein meals for animal nutrition, and insect fat for animal nutrition [17] and other purposes (e.g., biodiesel production) [18]. The defatted meal, being richer in crude protein $(\mathrm{CP})$ than soybean meal $(\mathrm{SBM})$, could find a place as a protein-rich source in fish diets. Till now few researchers have dealt with the use of defatted insect meals in fish nutrition [12, 19].

Among insects, black soldier fly (Hermetia illucens L.) is a very promising species to be used in aquaculture nutrition. Some research using fish fed different dietary inclusion levels of $H$. illucens (HI) larvae meals has reported growth performances in line with those of fish fed conventional protein sources (mainly FM or SBM). Newton et al. [20] reported similar weight gain for channel catfish (Ictalurus punctatus Rafinesque) fingerlings fed diets containing up to $30 \%$ of full-fat $\mathrm{HI}$ prepupae larvae meal. Including $15 \%$ of a full-fat $\mathrm{HI}$ prepupae meal, St-Hilaire et al. [8] were able to substitute $25 \%$ of FM without negative effects on rainbow trout (Oncorhynchus mykiss Walbaum) growth performance. In a trial using diets formulated to contain 18 and 36\% of $\mathrm{HI}$ meal from prepupae reared on substrates enriched with fish by-products, Sealey et al. [9] obtained similar growth performance of rainbow trout fed a control diet containing anchovy meal (substitution level: 25 and $50 \%$ on dry weight basis). Increased levels of $n 3$ polyunsaturated fatty acids (PUFA) contents were reported in the fillets of the fish fed HI reared on substrates enriched with fish by-products. In juvenile turbot (Psetta maxima L.), no significant effects on feed intake and feed conversion ratio (FCR) were observed with a diet containing up to 33\% of full-fat HI larvae meal [19]. In Atlantic salmon (Salmo salar L.), two different HI larvae meals, varying in their protein and fat contents, were tested in partial or total substitution of FM; the FM replacement led to controversial results depending on the type of $\mathrm{HI}$ meal used [12]. In the same trial, good protein and lipid digestibility was found.

Digestive capacity and histology of liver and gastrointestinal tract are usually investigated in fish when dietary modifications occur. Until now only one study on the effects of dietary HI larvae on liver, kidney, mid- and hind-intestine histology in Atlantic salmon has been performed [12]. Intestinal morphology is considered the main indicator of gut health and functional status, and it is generally assessed through morphometric measurements of the crypts and villi [21]. The effects of dietary modifications on the intestinal morphology using morphometric investigations have been evaluated in several livestock species, such as poultry [22], pigs [23] and rabbits [24], while in salmonids only few works are currently available [25]. 
In EU, the recent authorization of insect PAPs in aquaculture feeds requires further investigations to fully assess the potential inclusion of these innovative raw materials as well as the implications on the productive indexes and product quality parameters. So far, no investigations on rainbow trout have been performed using defatted HI meals and based on the above reported background, this research evaluated the effects of a partially defatted HI larvae meal on in vivo digestibility, growth performance, condition factor, somatic indexes, fillet physical and chemical quality, and intestinal morphology of rainbow trout.

\section{Methods}

The trial was conducted at the Experimental Facility of the Department of Agricultural, Forest, and Food Sciences (DISAFA) of the University of Torino (Italy). The experimental protocol was designed according to the guidelines of the current European and Italian laws on the care and use of experimental animals (European directive 86,609/EEC, put into law in Italy with D.L. 116/92).

\section{Diets}

A partially defatted HI larvae meal obtained processing larvae reared on vegetable by-products substrate was purchased from Hermetia Deutschland $\mathrm{GmbH}$ \& Co. KG (Baruth/Mark, Germany) and used in the trial. HI larvae meal was partially defatted with a mechanical process performed using high pressure and without solvents. No other information was provided by the producer on substrate or processing methodologies as they are considered confidential. Three experimental diets were formulated to be isonitrogenous (crude protein - CP: about $45 \mathrm{~g} / 100 \mathrm{~g}$ dry matter -DM), isolipidic (ether extract - EE: about $15 \mathrm{~g} / 100 \mathrm{~g} \mathrm{DM}$ ), and isoenergetic (gross energy GE: about $22 \mathrm{MJ} / \mathrm{kg} \mathrm{DM})$. The diets were obtained including, as fed basis, increasing levels of HI larvae meal in substitution of $0 \%$ (HI0), 25\% (HI25), and $50 \%$ (HI50) of FM, corresponding to dietary inclusion levels of $0 \%, 20 \%$ and $40 \%$. Due to the different chemical composition of HI compared to FM, and in order to maintain diets isonitrogenous, isolipidic and isoenergetic, with the increase of $\mathrm{HI}$ inclusion in the diets some other dietary ingredients (fish oil and wheat bran) were modified.

The experimental feeds were prepared at the DISAFA Experimental Facility. The grounded ingredients and fish oil were thoroughly mixed; water was then added to the mixture to attain an appropriate consistency for pelleting. Pellets were obtained using a $2.5 \mathrm{~mm}$ die meat grinder and dried at $50{ }^{\circ} \mathrm{C}$ for $48 \mathrm{~h}$. The diets were stored in dark bags at $-20{ }^{\circ} \mathrm{C}$ until utilisation. The ingredients of the experimental diets are reported in Table 1.
Table 1 Ingredients and proximate composition of HI larvae meal and experimental diets

\begin{tabular}{|c|c|c|c|c|}
\hline Items & HI larvae meal & $\mathrm{HIO}$ & $\mathrm{HI} 25$ & $\mathrm{HI} 50$ \\
\hline \multicolumn{5}{|l|}{ Ingredients, g/kg } \\
\hline FM (Chile, super prime) ${ }^{a}$ & - & 600 & 450 & 300 \\
\hline HI larvae meal ${ }^{b}$ & & 0 & 200 & 400 \\
\hline Wheat meal & - & 40 & 40 & 40 \\
\hline Wheat bran & - & 90 & 60 & 30 \\
\hline Fish oil & - & 90 & 70 & 50 \\
\hline Starch gelatinized, D500 & - & 150 & 150 & 150 \\
\hline Mineral mixture ${ }^{c}$ & - & 15 & 15 & 15 \\
\hline Vitamin mixture $^{d}$ & - & 15 & 15 & 15 \\
\hline \multicolumn{5}{|l|}{ Proximate composition ${ }^{\mathrm{e}}$} \\
\hline $\mathrm{DM}, \mathrm{g} / 100 \mathrm{~g}$ & 94.18 & 96.07 & 94.93 & 95.63 \\
\hline$C P, g / 100 \mathrm{~g} \mathrm{DM}$ & 55.34 & 45.20 & 44.86 & 45.00 \\
\hline $\mathrm{EE}, \mathrm{g} / 100 \mathrm{~g} \mathrm{DM}$ & 17.97 & 15.86 & 15.74 & 15.81 \\
\hline Ash, g/100 g DM & 7.12 & 11.40 & 11.43 & 10.11 \\
\hline Chitin, g/100 g DM & 5.00 & - & 1.05 & 2.09 \\
\hline NFE, g/100 g DM ${ }^{f}$ & 14.57 & 27.54 & 26.92 & 26.99 \\
\hline Gross energy, MJ/kg DM ${ }^{g}$ & 24.37 & 21.71 & 22.35 & 22.60 \\
\hline
\end{tabular}

Abbreviations: HI Hermetia illucens, FM fish meal, DM dry matter, $C P$ crude protein, EE ether extract, NFE Nitrogen Free Extracts

${ }^{a}$ Fish meal was purchased from Corpesca S.A. (Santiago, Chile). Proximate composition (\% as-fed basis): 90.4 DM; 66.7 CP; 8.3 EE; 14.9 Ash

${ }^{\mathrm{b}}$ Hermetia illucens larvae meal purchased from Hermetia Deutschland GmbH \& Co. KG (Baruth/Mark, Germany)

${ }^{\mathrm{C}}$ Mineral mixture ( $\mathrm{g}$ or $\mathrm{mg} / \mathrm{kg}$ diet): bicalcium phosphate $500 \mathrm{~g}$, calcium carbonate $215 \mathrm{~g}$, sodium salt $40 \mathrm{~g}$, potassium chloride $90 \mathrm{~g}$, magnesium chloride $124 \mathrm{~g}$, magnesium carbonate $124 \mathrm{~g}$, iron sulfate $20 \mathrm{~g}$, zinc sulfate $4 \mathrm{~g}$, copper sulfate $3 \mathrm{~g}$, potassium iodide $4 \mathrm{mg}$, cobalt sulfate $20 \mathrm{mg}$, manganese sulfate $3 \mathrm{~g}$, sodium fluoride $1 \mathrm{~g}$ (Granda Zootecnici, Cuneo, Italy)

dVitamin mixture (IU or $\mathrm{mg} / \mathrm{kg}$ diet): DL-atocopherolacetate, $60 \mathrm{IU}$; sodium menadione bisulfate, $5 \mathrm{mg}$; retinylacetate, 15,000 IU; DL-cholecalciferol, $3000 \mathrm{IU}$; thiamin, $15 \mathrm{mg}$; riboflavin, $30 \mathrm{mg}$; pyridoxine, $15 \mathrm{mg}$; Vitamin $\mathrm{B}_{12}$, $0.05 \mathrm{mg}$; nicotinic acid, $175 \mathrm{mg}$; folic acid, $500 \mathrm{mg}$; inositol, $1000 \mathrm{mg}$; biotin, $2.5 \mathrm{mg}$; calcium panthotenate, $50 \mathrm{mg}$; choline chloride, $2000 \mathrm{mg}$ (Granda Zootecnici, Cuneo, Italy)

'Values are reported as mean of duplicate analyses

${ }^{f}$ Calculated as $100-(\mathrm{CP}+\mathrm{EE}+\mathrm{Ash}+$ Chitin $)$

${ }^{9}$ Determined by calorimetric bomb

\section{Chemical analyses of feeds}

The proximate composition and energy level of the HI larvae meal and of the experimental diets are shown in Table 1. Feed samples were ground using a cutting mill (MLI 204; Bühler AG, Uzwil, Switzerland) and analysed for DM (AOAC \#934.01), CP (AOAC \#984.13) and ash (AOAC \#942.05) contents according to AOAC International [26]; EE (AOAC \#2003.05) was analyzed according to AOAC International [27]. The GE content was determined using an adiabatic calorimetric bomb (C7000; IKA, Staufen, Germany). Chitin was analyzed as D-Glucosamine [28] using a modification of the method described by Madrid et al. [29] for AA.

The AA composition of $\mathrm{HI}$ larvae meal and experimental diets is shown in Table 2. AA determination was performed according to the method described in De 
Table 2 Amino acid (AA) concentration (\% of protein) of $\mathrm{HI}$ larvae meal and experimental diets

\begin{tabular}{lllll}
\hline Items & Hl larvae meal & HIO & HI25 & HI50 \\
\hline Essential AA & & & & \\
Arginine & 3.9 & 6.3 & 5.7 & 5.0 \\
Histidine & 2.2 & 2.4 & 2.4 & 2.3 \\
Isoleucine & 3.3 & 4.2 & 4.0 & 3.7 \\
Leucine & 5.2 & 7.2 & 6.7 & 6.2 \\
Lysine & 3.8 & 7.4 & 6.5 & 5.6 \\
Methionine & 2.1 & 2.7 & 2.4 & 2.1 \\
Cysteine & 0.1 & 0.9 & 0.7 & 0.5 \\
Phenylalanine & 3.0 & 3.9 & 3.7 & 3.5 \\
Tyrosine & 4.8 & 3.0 & 3.5 & 3.9 \\
Threonine & 3.1 & 4.1 & 3.8 & 3.6 \\
Valine & 4.9 & 4.9 & 4.9 & 4.9 \\
Non essential AA & & & & \\
Alanine & 6.2 & 6.1 & 6.2 & 6.2 \\
Aspartic acid & 6.7 & 9.0 & 8.5 & 7.8 \\
Glycine & 4.2 & 1.0 & 1.7 & 2.6 \\
Glutamic acid & 8.8 & 7.2 & 7.6 & 8.0 \\
Proline & 5.5 & 12.4 & 10.6 & 9.0 \\
Serine & 3.7 & 4.2 & 4.0 & 3.9 \\
\hline
\end{tabular}

Marco et al. [5]. After a $22 \mathrm{~h}$ hydrolysis step in $6 \mathrm{~N} \mathrm{HCl}$ at $112{ }^{\circ} \mathrm{C}$ under a nitrogen atmosphere, the AA content in hydrolysate was determined by means of HPLC after postcolumn derivatization. Performic acid oxidation occurred prior to acid hydrolysis for methionine and cysteine. Tryptophan was not determined.

The FA composition of HI larvae meal and of the experimental diets was assessed using the method described by Schmid et al. [30]. Fatty acid methyl esters (FAME) were separated, identified and quantified on the basis of the chromatographic conditions reported by Renna et al. [31]. The results were expressed as g/100 g of total detected fatty acids (TFA) (Table 3).

\section{Digestibility trial}

An in vivo digestibility experiment was performed to determine the apparent digestibility coefficients (ADC) of the diets.

Thirty-six trout (weight $182.4 \pm 8.3 \mathrm{~g}$ ) were divided into twelve 40-L cylindroconical tanks connected to the same open water system of the growth trial. After 14 days of acclimatization with the experimental diets, the fish were fed by hand to visual satiety twice a day. The apparent digestibility coefficients were measured using the indirect acid-insoluble ash method; $1 \%$ celite $^{\varpi}$ (Fluka, St. Gallen, Switzerland) was added to the diets as inert marker in substitution of $1 \%$ of starch gelatinized
Table 3 Fatty acid composition (g/100 g of TFA) of HI larvae meal and experimental diets

\begin{tabular}{|c|c|c|c|c|}
\hline Items & HI larvae meal & $\mathrm{HIO}$ & $\mathrm{HI} 25$ & $\mathrm{HI} 50$ \\
\hline $\mathrm{C10:0}$ & 1.32 & 0.00 & 0.16 & 0.31 \\
\hline $\mathrm{C} 12: 0$ & 54.59 & 0.12 & 14.76 & 28.27 \\
\hline C14:0 & 10.14 & 5.78 & 7.25 & 8.39 \\
\hline$C 14: 1 C+C 15: 0$ & 0.51 & 0.57 & 0.56 & 0.53 \\
\hline C15 iso & 0.01 & 0.21 & 0.16 & 0.11 \\
\hline C16:0 & 12.03 & 18.84 & 17.92 & 16.52 \\
\hline C16 iso & 0.02 & 0.09 & 0.08 & 0.06 \\
\hline C16:1 C & 3.94 & 6.23 & 3.73 & 3.42 \\
\hline C17 iso & 0.02 & 0.56 & 0.41 & 0.28 \\
\hline C17 aiso & 0.10 & 0.29 & 0.27 & 0.24 \\
\hline C17:1 C9 & 0.08 & 0.28 & 0.22 & 0.19 \\
\hline C18:0 & 1.77 & 4.66 & 3.96 & 3.17 \\
\hline C18:1 t & 0.09 & 0.18 & 0.14 & 0.12 \\
\hline C18:1 C9 & 7.98 & 22.47 & 19.46 & 16.46 \\
\hline C18:1 C11 & 0.28 & 3.85 & 3.05 & 2.02 \\
\hline C18:2 n6 & 5.98 & 8.68 & 8.07 & 7.34 \\
\hline C18:3 n6 & 0.05 & 3.33 & 2.46 & 1.58 \\
\hline C18:3 n3 & 0.79 & 2.31 & 1.94 & 1.55 \\
\hline C20:0 & 0.10 & 0.28 & 0.27 & 0.18 \\
\hline C20:1 c9 & 0.00 & 0.15 & 0.13 & 0.08 \\
\hline C20:1 C11 & 0.00 & 0.30 & 0.21 & 0.15 \\
\hline C20:2 n6 & 0.02 & 1.95 & 1.34 & 0.86 \\
\hline C20:3 n6 & 0.00 & 0.14 & 0.10 & 0.06 \\
\hline C20:4 n6 & 0.00 & 0.75 & 0.53 & 0.33 \\
\hline C20:5 n3 & 0.00 & 7.83 & 5.59 & 3.37 \\
\hline C22:0 & 0.03 & 0.13 & 0.12 & 0.09 \\
\hline C22:1 n9 & 0.00 & 2.73 & 1.96 & 1.21 \\
\hline C22:5 n3 & 0.00 & 1.53 & 1.10 & 0.63 \\
\hline C22:6 n3 & 0.00 & 5.78 & 4.07 & 2.50 \\
\hline$\Sigma$ SFA & 80.28 & 30.96 & 45.35 & 57.61 \\
\hline$\Sigma$ MUFA & 12.88 & 36.75 & 29.46 & 24.17 \\
\hline$\sum$ PUFA & 6.84 & 32.29 & 25.19 & 18.22 \\
\hline$\Sigma$ PUFA/ $\Sigma$ MUFA & 0.09 & 1.04 & 0.56 & 0.32 \\
\hline$\sum \mathrm{n} 3$ & 0.79 & 17.45 & 12.69 & 8.05 \\
\hline$\sum \mathrm{n} 6$ & 6.05 & 14.83 & 12.50 & 10.17 \\
\hline$\Sigma \mathrm{n} 3 / \Sigma \mathrm{n} 6$ & 0.13 & 1.18 & 1.02 & 0.79 \\
\hline
\end{tabular}

Abbreviations: HI Hermetia illucens, c cis, $t$ trans, SFA saturated fatty acids, MUFA monounsaturated fatty acids, PUFA polyunsaturated fatty acids, TFA total fatty acids

All values are reported as mean of triplicate analyses

(D500). The faeces were collected daily from each tank for three consecutive week, using a continuous automatic device, as described by Palmegiano et al. [32]. The faeces were freeze dried and frozen $\left(-20{ }^{\circ} \mathrm{C}\right)$ until analyzed. The $\mathrm{ADC}$ of $\mathrm{DM}\left(\mathrm{ADC}_{\mathrm{DM}}\right)$, crude protein 
$\left(\mathrm{ADC}_{\mathrm{CP}}\right)$, ether extract $\left(\mathrm{ADC}_{\mathrm{EE}}\right)$ and gross energy $\left(\mathrm{ADC}_{\mathrm{GE}}\right)$ were calculated following Palmegiano et al. [32].

\section{Growth trial \\ Fish and rearing conditions}

A 78-day trial was carried out on three hundred sixty mixed-sex rainbow trout purchased from a private fish hatchery ("Troticoltura Bassignana"; Cuneo, Italy). At the beginning of the trial, fish were lightly anesthetised (MS-222; PHARMAQ Ltd., UK), individually weighed $(178.9 \pm 9.81 \mathrm{~g})$ and randomly divided into twelve indoor fiberglass tanks of $1 \mathrm{~m}^{3}$ (four replicate tanks per diet). Artesian well water (constant temperature of $13 \pm 1{ }^{\circ} \mathrm{C}$ ) was supplied in flow-through open system with each tank having a water inflow of $8 \mathrm{~L} / \mathrm{min}$. Dissolved oxygen was measured every fortnight and ranged between 7.6 and $8.7 \mathrm{mg} / \mathrm{L}$. Feed was distributed by hand twice a day, 7 days per week. The first week, the daily quantity of feed distributed was set at $1.2 \%$ of the tank biomass and it was then increased at $1.5 \%$. Feed intake was checked at each administration: all the supplied feed was consumed and no feed refusals were recorded during the trial. In order to update the daily FR, the biomass tanks were weighed in bulk every 14 days. Mortality was checked every day.

\section{Growth performance}

At the end of the trial, after 1 day of starving, all fish were individually weighed and the following performance indexes were calculated:

- Survival (\%) = $100-[$ (number of dead fish/number of fish at start $) \times 100$ ]

- Weight gain (WG, g) = FBW (final body weight, g) - IBW (initial body weight, g)

- Specific growth rate $(\mathrm{SGR}, \% / \mathrm{d})=[(\operatorname{lnFBW}-$ $\ln (B W) /$ number of feeding day] $\times 100$

- Feed conversion ratio $(\mathrm{FCR})=$ total feed supplied $(\mathrm{g}$, $\mathrm{DM}) / \mathrm{WG}(\mathrm{g})$

- Protein efficiency ratio (PER) $=\mathrm{WG}(\mathrm{g}) /$ total protein fed (g, DM)

- Feeding rate $(\mathrm{FR}, \% / \mathrm{d})=[$ (total feed supplied $(\mathrm{g}$, $\mathrm{DM}) \times 100 /$ number of feeding day $)] /\left[\mathrm{e}^{(\operatorname{lnFBW}+\ln I B W)}\right.$ $\times 0.5]$.

\section{Condition factor, somatic indexes and fillet physical quality parameters}

Twenty fish per treatment (five fish per tank) were killed by over anaesthesia. An image of each specimen was recorded with a digital camera (Nikon D3100; Minato, Tokyo, Japan) and fish length was measured using Image-Pro Plus 5.1 software (Media Cybernetics Inc., Bethesda, Rockville, MD, USA) to determine the Fulton's condition factor (K). The fish were dissected to determine the carcass yield $(\mathrm{CY})$, the hepatosomatic index (HSI), the viscerasomatic index (VSI) and the coefficient of fatness (CF). The somatic indexes were obtained as follows:

- $\left.\mathrm{K}=[\text { fish weight }(\mathrm{g}) / \text { (body length })^{3}(\mathrm{~cm})\right] \times 100$

- $\mathrm{CY}(\%)=[$ total weight without gut and gonad (g)/ fish weight $(\mathrm{g})] \times 100$

- HSI $(\%)=[$ liver weight $(\mathrm{g}) /$ fish weight $(\mathrm{g})] \times 100$

- VSI $(\%)=$ [gut weight $(\mathrm{g}) /$ fish weight $(\mathrm{g})] \times 100$

- $\mathrm{CF}(\%)=[$ perivisceral fat weight $(\mathrm{g}) /$ fish weight $(\mathrm{g})] \times 100$

The fish carcasses were then refrigerated $\left(+4{ }^{\circ} \mathrm{C}\right)$ and physical parameters determined $24 \mathrm{~h}$ after death. The fish were filleted and the muscle $\mathrm{pH}\left(\mathrm{pH}_{24}\right)$ was measured on each right dorsal fillet using a Crison MicropH 2001 (Crison Instruments, Barcelona, Spain) equipped with a combined electrode and an automatic temperature compensator. The flesh colour was assessed on the inside portion of each left dorsal fillet using a bench colorimeter ChromaMeter CR-400 Konica Minolta Sensing (Minolta Sensing Inc., Osaka, Japan). The results were expressed in terms of lightness $\left(\mathrm{L}^{*}\right)$, redness $\left(\mathrm{a}^{*}\right)$ and yellowness $\left(\mathrm{b}^{*}\right)$ in the CIELAB colour space model [33]. Two colour readings were taken on each fillet and averaged.

\section{Fillet chemical composition and fatty acid profile}

The left dorsal fillets of eight fish per treatment (two fish per tank) were finely ground (cutting mill MLI 204; Bühler AG, Uzwil, Switzerland) and freeze dried (Edwards MF 1000, Milan, Italy). DM, CP, EE, ash contents and the FA composition of the fillets were determined as described in Belforti et al. [34]; FAME peaks were identified by injecting pure FAME standards as detailed by Renna et al. [35]. Fillet chemical composition was expressed as $\mathrm{g} / 100 \mathrm{~g}$ wet weight (WW), while FA results were expressed as $g / 100 \mathrm{~g}$ of TFA.

The atherogenicity (AI) and thrombogenicity (TI) indexes of fish muscles were calculated. In these indexes, different weights are attributed to various categories of fatty acids in relation to their different contribution to the prevention or promotion of coronary heart diseases and precisely:

$$
\mathrm{AI}=(\mathrm{aC} 12: 0+\mathrm{bC} 14: 0+\mathrm{cC} 16: 0) /\left(\mathrm{dP}+\mathrm{eM}+\mathrm{fM}^{\prime}\right)
$$

where: $\mathrm{P}$ is the sum of $\mathrm{n} 3$ and $\mathrm{n} 6$ PUFA; $\mathrm{M}$ is the oleic acid and $\mathrm{M}^{\prime}$ is the sum of other monounsaturated fatty acids (MUFA); a, b, c, d, e, f are empirical constant; $\mathrm{b}=4$ and other constants $=1$. 


$$
\mathrm{TI}=(\mathrm{C} 14: 0+\mathrm{C} 16: 0+\mathrm{C} 18: 0) /\left[\left(\mathrm{nM}+\mathrm{oM}^{\prime}+\mathrm{p}(\mathrm{n} 6)+\mathrm{q}(\mathrm{n} 3)+(\mathrm{n} 3 / \mathrm{n} 6)\right]\right.
$$

where $\mathrm{M}$ and $\mathrm{M}^{\prime}$ are as before; $\mathrm{n}, \mathrm{o}, \mathrm{p}, \mathrm{q}$ are empirical constants; $\mathrm{n}, \mathrm{o}, \mathrm{p}=0.5$ and $\mathrm{q}=3$.

\section{Morphometric investigations}

At the end of the growth trial, morphometric investigations on intestinal tract were made on sixteen fish per treatment (four fish per tank). Anterior intestinal segment samples (approximately $5 \mathrm{~cm}$ in length) were excised and flushed with $0.9 \%$ saline to remove all the contents. Gut segments were fixed in $10 \%$ buffered formalin solution, routinely embedded in paraffin wax blocks, sectioned at $5 \mu \mathrm{m}$ thickness, mounted on glass slides and stained with Haematoxylin \& Eosin. Morphometric analysis using the Image Pro-Plus software were performed for each fish on 10 well-oriented and intact villi. The evaluated morphometric index was the villus height (from the tip of the villus to the submucosa).

\section{Statistical analyses}

Data were analyzed by one-way ANOVA using IBM SPSS Statistics 20.0. The following model was used:

$$
\mathrm{Y}_{\mathrm{ij}}=\mu+\mathrm{D}_{\mathrm{i}}+\varepsilon_{\mathrm{ij}}
$$

where $\mathrm{Y}_{\mathrm{ij}}=$ observation; $\mu=$ overall mean; $\mathrm{D}_{\mathrm{i}}=$ effect of diet (HI0, HI25, HI50); $\varepsilon_{\mathrm{ij}}=$ residual error.

The Kolmogorov-Smirnov test was used to check dependent variables for normality. The assumption of equal variances was assessed by Levene's homogeneity of variance test. If such an assumption did not hold, the Brown-Forsythe statistic was performed to test for the equality of group means instead of the $\mathrm{F}$ one. Pairwise multiple comparisons were performed to test the difference between each pair of means (Tukey's test and Tamhane's T2 in the cases of equal variances assumed or not assumed, respectively).

The results were expressed as mean and pooled standard error of the mean (SEM). Significance was declared at $P \leq 0.05$

\section{Results}

\section{Diets}

All diets were comparable in terms of DM and other main nutrients. The GE ranged between 21.71 and $22.60 \mathrm{MJ} / \mathrm{kg} \mathrm{DM}$. The AA compositions of HI larvae meal and the three assay diets are presented in Table 2. In the HI meal among essential AA (EAA), leucine, tyrosine and valine were the most abundant, whereas glutamic and aspartic acid were the most abundant non essential AA. HI larvae meal reported similar values for histidine and lower values for arginine and lysine than FM [36]. Concerning diet EAA profile, tyrosine increased at the increasing dietary $\mathrm{HI}$ inclusion levels.
Conversely, all the other EAA decreased except histidine and valine that remain constant. As far as the FA composition is concerned (Table 3), lauric acid (C12:0) was by far the most represented FA in HI larvae meal (54.59 g/100 g of TFA). Consequently, in the experimental diets lauric acid and total saturated fatty acids (SFA) increased following the increased inclusion of insect meal. Arachidonic (C20:4 n6), eicosatrienoic (C20:3 n6), eicosapentaenoic (EPA, C20:5 n3), docosapentaenoic (DPA, C22:5 n3) and docosahexaenoic (DHA, C22:6 n3) acids were not detected in the HI larvae meal; their contents consequently decreased in the experimental diets with the increase of insect meal inclusion level. Such decreases have also to be imputed to the contemporary decrease in the fish oil content of the diets. The total $n 3$ and $\mathrm{n} 6$ contents in the diets decreased from 17.45 (HI0) to 8.05 (HI50) and from 14.83 (HI0) to 10.17 (HI50) g/ $100 \mathrm{~g}$ of TFA, respectively. The $\sum \mathrm{n} 3 / \sum \mathrm{n} 6$ FA ratio decreased in the diets following the increase of HI larvae meal inclusion.

\section{Digestibility trial}

The ADC values of nutrients are presented in Table 4. Differences $(P<0.05)$ were recorded between HI25 and HI50 for DM and CP digestibility. In both cases, HI25 showed the highest values.

\section{Growth trial \\ Growth performance}

The survival (\%) and growth performance parameters are reported in Table 5 . No differences $(P>0.05)$ were observed for the considered parameters. Fish survival ranged from $97.4 \%$ (HI0) to $100 \%$ (HI50). The fish readily accepted the experimental diets. All feeds were consumed without rejection or loss. IBW was comparable among the treatments and in 78 days the fish tripled their BW. FCR remained below 1 in all treatments.

Table 4 Apparent digestibility coefficient of dry matter, proteins, ether extract and gross energy of rainbow trout fed the experimental diets $(n=4)$

\begin{tabular}{llllll}
\hline Items & $\mathrm{HIO}$ & $\mathrm{H} 125$ & $\mathrm{H} 150$ & $\mathrm{SEM}$ & $P$-value \\
\hline ADC $_{\mathrm{DM}}$ & $0.76 \mathrm{ab}$ & $0.79 \mathrm{a}$ & $0.74 \mathrm{~b}$ & 0.009 & 0.012 \\
$\mathrm{ADC}_{\mathrm{CP}}$ & $0.89 \mathrm{ab}$ & $0.91 \mathrm{a}$ & $0.87 \mathrm{~b}$ & 0.006 & 0.023 \\
$\mathrm{ADC}_{\mathrm{EE}}$ & 0.97 & 0.99 & 0.97 & 0.005 & 0.245 \\
ADC $_{\mathrm{GE}}$ & 0.60 & 0.65 & 0.60 & 0.012 & 0.100 \\
\hline
\end{tabular}

Abbreviations: HI Hermetia illucens, SEM standard error of the mean, $P$ probability, $A D C_{D M}$ dry matter apparent digestibility coefficient, $A D C_{C P}$ crude protein apparent digestibility coefficient, $A D C_{E E}$ ether extract apparent digestibility coefficient, $A D C_{G E}$ gross energy apparent digestibility coefficient Different letters within a row indicate significant differences $(P \leq 0.05)$ 
Table 5 Survival and growth performances of rainbow trout fed the experimental diets $(n=4)$

\begin{tabular}{llllll}
\hline Items & HIO & HI25 & HI50 & SEM & $P$-value \\
\hline Survival,\% & 97.4 & 98.3 & 100.0 & 0.681 & 0.298 \\
IBW,g & 178.9 & 178.8 & 179.1 & 0.099 & 0.579 \\
FBW,g & 539.3 & 545.4 & 538.0 & 5.098 & 0.849 \\
WG,g & 360.5 & 366.5 & 358.9 & 5.079 & 0.840 \\
SGR,\%/d & 1.40 & 1.42 & 1.41 & 0.013 & 0.935 \\
FCR & 0.90 & 0.88 & 0.90 & 0.009 & 0.739 \\
PER & 2.46 & 2.52 & 2.47 & 0.024 & 0.579 \\
FR,\%/d & 1.33 & 1.32 & 1.33 & 0.005 & 0.442 \\
\hline A 6 r
\end{tabular}

Abbreviations: HI Hermetia illucens, SEM standard error of the mean, $P$ probability, IBW initial body weight, $F B W$ final body weight, WG weight gain, $S G R$ specific growth rate, FCR feed conversion ratio, PER protein efficiency ratio, FR feeding rate

\section{Condition factor, somatic indexes and fillet physical quality parameters}

No differences were highlighted for condition factor, somatic indexes, carcass characteristics and physical quality traits (pH and color) of the fillets (Table 6).

\section{Fillet chemical composition and fatty acid profile}

The fillet chemical and FA compositions of the fish fed the experimental diets are reported in Table 7. Regarding the chemical composition, only $\mathrm{CP}$ remained unaffected by treatment. The inclusion of HI larvae meal progressively increased DM and EE contents in HI25 and HI50 compared to HIO $(P<0.05)$. The ash content was higher in HIO $(1.20 \mathrm{~g} / 100 \mathrm{~g}$ WW) compared to HI25 (1.00 g/ $100 \mathrm{~g}$ WW), while HI50 showed intermediate values.

Table 6 Condition factor, somatic indexes and fillet physical quality parameters of rainbow trout fed the experimental diets $(n=20)$

\begin{tabular}{llllll}
\hline Items & $\mathrm{HIO}$ & $\mathrm{HI25}$ & $\mathrm{HI} 50$ & $\mathrm{SEM}$ & $P$-value \\
\hline $\mathrm{K}$ & 1.18 & 1.23 & 1.21 & 0.011 & 0.198 \\
$\mathrm{CY}$ & 88.88 & 88.87 & 88.94 & 0.110 & 0.968 \\
$\mathrm{HSI}$ & 1.63 & 1.73 & 1.71 & 0.021 & 0.158 \\
$\mathrm{VSI}$ & 8.94 & 9.25 & 9.21 & 0.141 & 0.632 \\
$\mathrm{CF}$ & 1.57 & 1.41 & 1.39 & 0.066 & 0.472 \\
Quality parameters & & & & \\
\multicolumn{1}{c}{$\mathrm{pH}_{24}$} & 6.36 & 6.38 & 6.41 & 0.016 & 0.557 \\
\multicolumn{1}{c}{ L $^{*}$} & 45.06 & 46.38 & 47.98 & 0.618 & 0.157 \\
$\mathrm{a}^{*}$ & 0.24 & -0.25 & -0.29 & 0.187 & 0.434 \\
\multicolumn{1}{c}{$\mathrm{b}^{*}$} & 6.34 & 6.68 & 6.67 & 0.145 & 0.575 \\
Hue & -0.48 & -0.09 & -0.41 & 0.179 & 0.644 \\
Chroma & 6.50 & 6.86 & 6.77 & 0.153 & 0.608 \\
\hline
\end{tabular}

Abbreviations: HI Hermetia illucens, SEM standard error of the mean, $P$ probability, $K$ condition factor, $C Y$ carcass yield, $H S I$ hepatosomatic index, VSI viscerosomatic index, $\mathrm{CF}$ coefficient of fatness, $\mathrm{pH}_{24}$ fillet muscle $\mathrm{pH}$ at $24 \mathrm{~h}$ post mortem, $L^{*}$ lightness, $a^{*}$ redness, $b^{*}$ yellowness
Table 7 Fillets chemical and fatty acid compositions of rainbow trout fed the experimental diets $(n=8)$

\begin{tabular}{cccccc}
\hline Items & HIO & HI25 & HI50 & SEM & $P$-value \\
\hline \multicolumn{2}{c}{ Chemical composition, g/100 g WW } & & & \\
DM & $25.06 \mathrm{~b}$ & $25.79 \mathrm{ab}$ & $26.31 \mathrm{a}$ & 0.194 & 0.022 \\
$\mathrm{CP}$ & 19.58 & 19.37 & 19.56 & 0.064 & 0.360 \\
EE & $4.18 \mathrm{~b}$ & $5.19 \mathrm{ab}$ & $5.48 \mathrm{a}$ & 0.219 & 0.036 \\
Ash & $1.20 \mathrm{a}$ & $1.00 \mathrm{~b}$ & $1.09 \mathrm{ab}$ & 0.030 & 0.015
\end{tabular}

Fatty acid composition, $\mathrm{g} / 100 \mathrm{~g}$ of TFA

\begin{tabular}{|c|c|c|c|c|c|}
\hline C12:0 & $0.29 c$ & $8.07 b$ & $14.66 \mathrm{a}$ & 1.239 & 0.000 \\
\hline C14:0 & $3.97 c$ & $5.49 \mathrm{~b}$ & $6.47 \mathrm{a}$ & 0.224 & 0.000 \\
\hline$C 14: 1 C+C 15: 0$ & 0.40 & 0.47 & 0.43 & 0.014 & 0.072 \\
\hline C16:0 & $22.73 \mathrm{a}$ & $20.69 b$ & $20.38 \mathrm{~b}$ & 0.280 & 0.000 \\
\hline C16:1 C & 6.22 & 6.45 & 6.41 & 0.075 & 0.428 \\
\hline C17:0 & $0.49 \mathrm{a}$ & $0.41 b$ & $0.35 \mathrm{~b}$ & 0.015 & 0.000 \\
\hline $\mathrm{C} 17: 1 \mathrm{C9}$ & $0.05 b$ & $0.08 \mathrm{a}$ & $0.07 \mathrm{ab}$ & 0.004 & 0.002 \\
\hline C18:0 & $5.45 \mathrm{a}$ & $4.79 \mathrm{~b}$ & $4.64 \mathrm{~b}$ & 0.107 & 0.001 \\
\hline C18:1 t & $0.97 \mathrm{a}$ & $0.69 \mathrm{~b}$ & $0.66 \mathrm{~b}$ & 0.044 & 0.001 \\
\hline C18:1 c9 & $31.33 \mathrm{a}$ & $27.62 b$ & $26.37 b$ & 0.531 & 0.000 \\
\hline C18:1 C11 & $4.03 \mathrm{a}$ & $3.43 \mathrm{~b}$ & $2.91 \mathrm{c}$ & 0.102 & 0.000 \\
\hline C18:2 n6 & $10.30 \mathrm{a}$ & $9.46 \mathrm{ab}$ & $9.01 \mathrm{~b}$ & 0.208 & 0.027 \\
\hline C18:3 n6 & $3.05 \mathrm{a}$ & $2.29 \mathrm{~b}$ & $1.73 \mathrm{c}$ & 0.135 & 0.000 \\
\hline C18:3 n3 & $1.97 \mathrm{a}$ & $1.90 \mathrm{a}$ & $1.49 \mathrm{~b}$ & 0.066 & 0.002 \\
\hline C20:0 & $0.36 a$ & $0.36 \mathrm{a}$ & $0.23 \mathrm{~b}$ & 0.016 & 0.000 \\
\hline C20:1 C11 & $0.40 \mathrm{a}$ & $0.39 a$ & $0.25 b$ & 0.018 & 0.000 \\
\hline C20:2 n6 & $0.83 a$ & $0.74 a$ & $0.57 b$ & 0.030 & 0.000 \\
\hline C20:3 n6 & 0.30 & 0.27 & 0.29 & 0.007 & 0.442 \\
\hline C20:4 n6 & $0.49 a$ & $0.46 a$ & $0.29 \mathrm{~b}$ & 0.022 & 0.000 \\
\hline C20:5 n3 & $2.33 \mathrm{a}$ & $2.03 \mathrm{a}$ & $1.07 \mathrm{~b}$ & 0.133 & 0.000 \\
\hline C22:5 n3 & $0.66 \mathrm{a}$ & $0.50 \mathrm{~b}$ & $0.23 c$ & 0.038 & 0.000 \\
\hline C22:6 n3 & 3.39 a & $3.40 \mathrm{a}$ & $1.50 \mathrm{~b}$ & 0.203 & 0.000 \\
\hline$\sum$ SFA & $33.28 c$ & $39.81 \mathrm{~b}$ & $46.74 \mathrm{a}$ & 1.186 & 0.000 \\
\hline$\Sigma$ MUFA & $43.40 \mathrm{a}$ & $39.13 b$ & $37.09 \mathrm{c}$ & 0.623 & 0.000 \\
\hline$\sum$ PUFA & $23.31 \mathrm{a}$ & $21.06 \mathrm{~b}$ & $16.17 \mathrm{c}$ & 0.693 & 0.000 \\
\hline$\Sigma \mathrm{PUFA} / \Sigma \mathrm{SFA}$ & $0.70 \mathrm{a}$ & $0.53 \mathrm{~b}$ & $0.35 c$ & 0.033 & 0.000 \\
\hline$\sum n 3$ & $8.34 \mathrm{a}$ & $7.84 \mathrm{a}$ & $4.29 \mathrm{~b}$ & 0.418 & 0.000 \\
\hline$\sum \mathrm{n} 6$ & $14.97 \mathrm{a}$ & $13.22 b$ & $11.88 \mathrm{c}$ & 0.309 & 0.000 \\
\hline$\sum n 3 / \sum n 6$ & $0.56 \mathrm{a}$ & $0.59 \mathrm{a}$ & $0.36 \mathrm{~b}$ & 0.024 & 0.000 \\
\hline $\mathrm{Al}$ & $0.58 c$ & $0.84 \mathrm{~b}$ & $1.15 \mathrm{a}$ & 0.050 & 0.000 \\
\hline TI & $0.60 \mathrm{~b}$ & $0.62 b$ & $0.85 \mathrm{a}$ & 0.026 & 0.000 \\
\hline
\end{tabular}

Abbreviations: HI Hermetia illucens, SEM standard error of the mean, WW wet weight, $D M$ dry matter, $C P$ crude protein, $E E$ ether extract, $c$ cis, $t$ trans, $F A$ fatty acids, SFA saturated fatty acids, MUFA monounsaturated fatty acids, PUFA polyunsaturated fatty acids, $A l$ atherogenicity index, $T /$ thrombogenicity index, TFA total fatty acids

Different letters within a row indicate significant differences $(P \leq 0.05)$ All values are reported as mean of triplicate analyses 
Concerning the fillet FA composition, C12:0 sharply increased (from 0.29 to 8.07 and $14.66 \mathrm{~g} / 100 \mathrm{~g}$ of TFA in HI0, HI25 and HI50 groups, respectively), showing highly significant differences among all treatments. Increasing trends were also observed for myristic acid (C14:0) and the total SFA content, which were both higher in HI25 compared to HI0 and in HI50 compared to HI25. The majority of individual MUFA were also affected by diet. Most of them showed a decreasing trend following the increase of HI larvae meal inclusion. Regarding PUFA, the total content decreased and showed highly significant differences among all treatments. Individual PUFA showed a decreasing trend from HIO to HI50, with the exception of eicosatrienoic acid (C20:3 n6) which was not affected by diet. EPA and DHA showed lower contents in HI50 compared to HIO and HI25, while DPA was already reduced at the lower inclusion level of HI meal. Overall, lipids health indexes such as the $\Sigma$ PUFA $/ \Sigma$ SFA ratio, the $\Sigma \mathrm{n} 3 / \Sigma$ n6 FA ratio, AI and TI were negatively affected by $\mathrm{HI}$ larvae meal inclusion in the diet. The $\Sigma$ PUFA $/ \Sigma$ SFA ratio and AI already worsened with the lower dietary HI larvae meal inclusion level, while for the $\Sigma \mathrm{n} 3 / \Sigma \mathrm{n} 6$ FA ratio and TI significant variations compared to the control diet were only observed with the higher dietary level of insect meal.

\section{Morphometric investigations}

Dietary HI inclusion did not affect the intestinal morphology of the trout of the present study $(\mathrm{HIO}=1.48 \mathrm{~mm}$; HI25 = $1.49 \mathrm{~mm}$; HI50 = $1.60 \mathrm{~mm}$; SEM = 0.039; $P>0.05)$.

\section{Discussion}

\section{Digestibility trial}

As far as digestibility is concerned, differences were only found for $\mathrm{ADC}_{\mathrm{DM}}$ and $\mathrm{ADC}_{\mathrm{CP}}$ between HI25 and HI50, while HIO showed intermediate values. The lowest values were recorded for HI50 ( 0.74 and 0.87 for DM and CP, respectively). Nevertheless, it has to be highlighted that in all treatments the digestibility of these nutrients was very good and higher than values reported for trout fed bacterial protein meal [37]. The good ADC values found in our trial support the growth performance results.

The lower levels of DM and CP digestibility in HI50 compared to HI25 could be attributed to the higher level of chitin supplied by the HI50 meal. These findings could be ascribed to the proteins linked to chitin and therefore present in the insect exoskeleton [38]. Even if gastrointestinal bacteria and chitinase activity were reported in some fish species [11], the chitin digestibility is usually very low or completely absent in rainbow trout [6]. Marono et al. [39] indicated that chitin is the main factor affecting the in vitro protein digestibility of $\mathrm{HI}$ meal and showed that CP digestibility was negatively correlated to the chitin content of the meal. Moreover, it has been shown that high concentrations (up to 45\%) of the chitin present in the cuticular exoskeleton of insects negatively affected feed intake and reduced protein digestibility [40]. Despite the decrease of CP digestibility in HI50 compared to HI25, no negative effects on trout growth performance were highlighted in this trial. Marono et al. [39] estimated that chitin content of different HI samples varied from 2.86 to $5.50 \%$ of the meal (average: $4.25 \%$ ). In our trial, a dietary inclusion of 20 or $40 \%$ of HI, replacing 25 or $50 \%$ of dietary FM, would thus have brought a maximal amount of $2 \%$ of chitin likely not being able to produce negative effects on trout performances.

No differences were found in our trial regarding $\mathrm{ADC}_{\mathrm{EE}}$ and $\mathrm{ADC}_{\mathrm{GE}}$ among treatments. Lock et al. [12] reported that the dietary inclusion of insect meal did not affect the FA digestibility in Atlantic salmon. These authors reported that the FA digestibility ranged between 82.5 and $100 \%$ and underlined how lauric acid remained highly digestible even in diets where it was highly abundant.

In comparison to other alternative animal protein sources, the $\mathrm{ADC}_{\mathrm{CP}}$ values found in our trial were higher than those observed for feather meal or meat and bone meal (81 and $83 \%$, respectively) for rainbow trout [4].

\section{Growth trial}

\section{Growth performance}

The results of the growth trial showed that the inclusion of 20 and $40 \%$ of a partially defatted HI larvae meal in substitution of 25 and $50 \%$ of FM in trout diets did not lead to any adverse effect on growth performance. The trout (all treatments merged) showed an average WG of about $4.7 \mathrm{~g} / \mathrm{d}$, indicating a good nutrient utilization. Such result is also supported by the very favourable FCR (all less than 1), the high PER (always greater than 2.4), and a SGR near to 1.4. No palatability problems were highlighted and the dietary inclusion of 20 and $40 \%$ of HI reduced the diet FM component from 60 to 45 and $30 \%$ respectively.

The results obtained in this trial do not always agree with those reported in other studies performed using HI. Indeed, St-Hilaire et al. [8], using a full fat HI prepupae meal, observed a decrease in WG and a worsening in FCR when HI prepupae meal was included in trout diets for more than 15\% (FM substitution of more than 25\%). It has to be highlighted that the initial body weight of trout used in the trial performed by St-Hilaire et al. [8] was $22.2 \mathrm{~g}$ and that young fish have higher requirements than adult fish as those used in the present trial. The huge difference in fish weight may partially explain the differences observed in growth performances between trials. StHilaire et al. [8] ascribed the reduced performances 
to a lower energy intake in fish fed insects compared to fish fed control diet. In our trial, the experimental diets contained equal amounts of GE. Moreover, the replacement of $50 \%$ of the FM component in St-Hilaire et al. [8] trial reduced to only $18 \%$ the FM dietary inclusion and, even if not suggested by authors, this could have led to a deficit in EAA.

Sealey et al. [9] used full-fat HI prepupae meals obtained from larvae reared on manure or manure enriched with fish by-products substrates. The FM substitution was 25 and $50 \%$ for both $\mathrm{HI}$ meals, leading to dietary inclusion rates of about 16 and 32\% for the former and of about 18 and $36 \%$ for the latter HI meal. Feeding rainbow trout of similar weight of those of the current trial (about $145 \mathrm{~g}$ ), these authors showed that WG of trout fed the enriched diets was lower but not different from that of trout fed the control diet, while it was reduced in trout fed the non-enriched HI diets. In both cases, no significant differences were reported for feed consumption and FCR. In addition to the use of a defatted HI meal, the differences observed in our study compared to the one of Sealey et al. [9], could be related to the HI meal nutrient availability. Indeed, Sealey et al. [9] suggested a lower nutrient availability in HI diets supporting their statement with a lower muscle lipid in fish fed both normal and enriched HI meals compared to fish fed the FM diet. In our trial an increase in lipid muscle content was reported suggesting a good nutrient availability.

In a study on rainbow trout fed diets containing 0,50 and $75 \%$ of full-fat $\mathrm{HI}$ meal in substitution of FM, Stamer et al. [41] concluded that the substitution up to $50 \%$ may be possible without negative effects on WG, FCR and PER. However, it has to be noted that, according to the information reported in Stamer et al. [41], it is difficult to understand the levels of inclusions of $\mathrm{HI}$ meal in the different treatments since no quantitative data regarding formulations is produced and it is not possible to extrapolate the quantity of FM used in control diet.

Kroeckel et al. [19], in a trial with turbot juveniles, formulated six diets containing increasing levels of $\mathrm{HI}$ meal (CP: 54.1\% DM; EE: 13.4\% DM). These authors found a decrease of feed intake while increasing HI incorporation due to low diet palatability. They also noted that growth performance was affected by dietary $\mathrm{HI}$ inclusion and reported lower FBW and SGR in all treatments containing HI, whereas FCR was worsened only at $\mathrm{HI}$ inclusion levels higher than 33\%. Similarly to Sealey et al. [9], Kroeckel et al. [19] reported a decrease in final body crude lipid content in fish fed HI diets (significant only over $33 \%$ of inclusion) denoting a decrease in nutrient availability as also supported by the low digestibility coefficients found for $\mathrm{HI}$ meal. These authors attributed the low lipid utilization and the small lipid retention at higher $\mathrm{HI}$ inclusion levels to the presence of chitin and its negative influence on lipid digestibility. Chitin contents in HI25 and HI50 diets used in the current trial (1 and $2 \%$ respectively) resulted lower than those reported by Kroeckel et al. [19] and these contents seem not sufficient to induce negative effects on trout performances.

Finally, Lock et al. [12] carried out a trial with salmon where FM ( $200 \mathrm{~g} / \mathrm{kg}$ diet) was substituted by 25,50 and $100 \% \mathrm{HI}$ (inclusion of 5, 10 and $20 \% \mathrm{HI}$ in the experimental diets). Their results showed that feed intake decreased moderately while increasing HI inclusion; however, FCR decreased resulting in an equal net growth of the fish.

Contrasting results of the over cited studies could also be ascribed to the type of insect meal, the level of fat in meals, the fish species and the fish age [6].

\section{Condition factor, somatic indexes and fillet physical quality parameters}

The Fulton's condition factor is used to compare the condition, fatness, or wellbeing of fish, based on the assumption that heavier fish of a given length are in better condition [42], $\mathrm{K}$ values less than 1 imply that fish are not in good state of well-being within their habitat, while values greater than 1 imply that fish are in good physiological state of well-being. The $\mathrm{K}$ values reported in our trial, independently from the treatment, were greater than 1 and were similar to those recorded in large rainbow trout fed a plant protein mixture [43]. These authors explained also that in trout a higher condition factor is mainly due to a high mesenteric fat content, suggesting higher fat synthesis and deposition. In our study, trout fed HI meal diets showed no differences both for $\mathrm{K}$ and $\mathrm{CF}$, therefore is reasonable that insect meal did not modify fat synthesis and deposition of the fish fed experimental diets.

As far as HSI is concerned, the obtained values were higher than those reported by Sealey et al. [9], which ranged between 1.1 to 1.2 , and no differences were found as a consequence of dietary inclusion of HI. In trout fed by graded levels of canola oil, Dernekbaşi [44] ascribed altered values of HSI to metabolic problems or liver deficiencies. The lack of HSI differences found in our trial among treatments seems to confirm the wellbeing status of the fish and that no problems arose by the ingestion of HI. In our trial, VSI did not differ among treatments. Such results partly differ from what reported by Lock et al. [12] who found different HSI and VSI values in Atlantic salmon fed diets containing two different $\mathrm{HI}$ meals if compared to a FM-based diet; the results obtained by Lock et al. [12] were however dependent on type of insect meal used and level of inclusion in the diet. Using Tenebrio molitor larvae meal in 
rainbow trout, Belforti et al. [34] found significant differences for HSI values, with a decrease of this index at the increase of insect meal levels in the diets, while no significant differences were observed for VSI among groups.

A decrease in nutrient availability is often associated to a decrease in the intraperitoneal fat ratio [9]. Similarly, some authors imputed to a low nutrient digestibility the decrease in $\mathrm{CY}$ when fish were fed FM substitutes $[45,37]$.

Variations in fillet $\mathrm{pH}$ values could be due to several factors like culture density, stress level prior to killing, dietary treatments and fillet energy storage [45]. Moreover, high $\mathrm{pH}$ could negatively influence the shelf life of the product because an alkaline environment is not able to inhibit microbial degradation processes. The magnitude of the $\mathrm{pH}$ decrease is species specific and in this study the values obtained for $\mathrm{pH}$ at $24 \mathrm{~h}$ post mortem are in line with those reported for trout fed two levels of lipids [46] and lower than those found by Gai et al. [37] in trout fed bacterial or plant protein meals. Fillet colour is a very important quality parameter since it is directly perceived by the consumer. In our trial, the use of HI did not influence colour parameters. To the best of our knowledge, no published data are currently available comparing fillet colour of trout fed HI meals and other diets. Trout fed plant proteins sometimes highlighted increased $b^{*}$ that could partially be attributed to the presence in the feeds of plant pigments like corn carotenoids [43]; this could negatively influence the consumer acceptance of the fillets [37, 45]. A direct relationship between fillets brightness and their lipid content was demonstrated in salmonids [47]. However, in our trial, no differences were recorded for $L^{*}(P=0.157)$, despite the observed EE increase in fillet following the dietary inclusion level of insect meal. Finally, a significant decrease for $L^{*}$ was reported by Pieterse et al. [48] in breast muscle of broilers fed diets containing Musca domestica larvae meals compared to a FM based diet.

\section{Fillet chemical composition and fatty acid profile}

The use of HI did not affect the net content of proteins in trout fillets. The obtained $\mathrm{CP}$ values are consistent with those found by Palmegiano et al. [32] and Gai et al. [37], who used alternative protein sources (rice protein concentrate meal and bacterial protein meal or pea protein concentrate, respectively) in rainbow trout feeds. Similarly, no change in the fillet protein content with the use of HI was obtained by Sealey et al. [9].

In the present study, the observed EE increase in fillet indicates a good availability and storage of nutrients in the trout fed HI. Such finding disagree with other authors $[9,19,34]$ who reported decreased values of DM and EE in the fillets of fish fed insect meals, probably due to a decrease in nutrient availability.
So far, this is the first trial on rainbow trout dealing with partially defatted HI. Former trials evaluated HI prepupae meals having an average fat content of about $30 \%[8,9]$. The FA profile of the partially defatted $\mathrm{HI}$ larvae meal used in this trial showed differences if compared to the ones used in researches performed by StHilaire et al. [8] or by Sealey et al. [9]. Differences could be due to the rearing substrates used. Indeed, while the present $\mathrm{HI}$ was obtained from larvae reared on vegetable by-products, the ones of St-Hilaire et al. [8] and of Sealey et al. [9] were obtained rearing black soldier fly on swine manure. The FA profile of fish usually mirrors that of the administered diets; as a consequence, a noticeable influence of $\mathrm{HI}$ on the fillet FA composition was observed in our trial. The content of lauric acid differed among all treatments, with values 27.8 and 50.6 times higher in the trout fed HI25 and HI50 compared to HIO, respectively. Even if to a lesser extent, this increase was also noticed for C14:0. The rise in lauric and myristic acids led to increased total SFA in the fillets of the trout fed HI diets if compared to those fed the control diet. As recently observed by $\mathrm{Li}$ et al. [17] in juvenile Jian carp (Cyprinus carpio var. Jian) fed HI larvae oil, we also found relatively lower levels of lauric acid in the muscles of HI-fed trout if compared to the respective lauric acid dietary levels, which may suggest readily utilization of this FA for energy production.

Conversely, for valuable very long chain $n 3$ PUFA (such as EPA and DHA), well known for their beneficial effects on human health, differences were only found between HI50 and the other two treatments. Such result could be due to the still high fish oil content of the HI25 diet and/or could suggest good elongation and desaturation activities in the HI25 group, probably due to a stimulation of the involved lipogenic enzymes, as suggested by Figueiredo-Silva et al. [49] and also reported by Lock et al. [12]. These results only partially agree with the findings of Belforti et al. [34] who found significant reductions of EPA and DHA in trout fillets starting from the lowest level of FM substitution with full-fat $T$. molitor meal. Similarly, the $\Sigma \mathrm{n} 3 / \Sigma \mathrm{n} 6$ FA ratio did not differ between HIO and HI25, modulating the negative effects on fish nutritional values when alternative proteins are used in rainbow trout feeds [9, 32, 34].

Fish is considered as a valuable food to prevent coronary heart diseases due to its high levels of PUFA. Indexes ( $\mathrm{AI}, \mathrm{TI})$ correlating the different amount of some specific SFA, MUFA and PUFA of both the $\mathrm{n} 3$ and $n 6$ series were proposed to indicate the contribution of these FAs to the prevention or promotion of pathological phenomena. Series n3 and n6 MUFA and PUFA are considered to have similar activity towards the prevention of thrombi onset, while n3 PUFA seem to be more important in the prevention of atheroma 
insurgence. There were differences in AI and TI of the fillets from the trout fed diets with different HI replacement levels. Anyway, the obtained values were less or around 1.0, still considered to be healthy for human consumers.

\section{Morphometric investigations}

Dietary HI inclusion did not induce morphological changes in the rainbow trout intestine, thus suggesting no negative influence on the intestinal physiological development. Our results are similar to what observed by Lock et al. [12], who found normal histology of the midgut epithelium in salmon fed insect larvae meals. Similar data were also obtained by Biasato et al. [50] who recently evaluated the histomorphological alterations in free-range chickens fed diets with $T$. molitor larvae meal inclusion, finding no differences related to insect meal utilization.

Despite lacking of information about gut morphometry in fish, in other species long villi have been reported to be associated with an increased population of beneficial bacteria in the gut [51]. Indeed, lengthening of villi may increase villus absorptive area, with subsequent satisfactory digestive enzyme action and greater transport of nutrients [52].

\section{Conclusions}

This study provided new data and knowledge on the potential use of a new sustainable feedstuff for carnivorous fish diets. The ADC values found in this trial were overall satisfactory. Main findings indicated that dietary FM can be replaced by a partially defatted HI larvae meal up to $50 \%$ of substitution ( $40 \%$ of inclusion in diet) without negative effects on growth performance, condition factor, somatic indexes, physical quality parameters and gut morphology. The fillet chemical composition was influenced by the use of insect meal with the exception of $\mathrm{CP}$ content. From the lipid point of view, HI exerted negative effects both on EE content and FA composition. Nevertheless, it can be stated that up to $20 \%$ of HI dietary inclusion, no negative effects were reported as far as the contents of beneficial very long chain n3 FA (EPA and DHA) are concerned.

Insect meals have recently been authorized for aquafeed. Notwithstanding, commercial business application needs future research. Particularly, information on the influence of insect meals on feed physical characteristics in extruded aquafeeds is still missing. Moreover, insect meal producers still face with the problem of insect meal chitin content. Therefore the assessment of methods to improve the digestibility of insect meals for their correct introduction as raw material in fish feeds are needed.

\section{Abbreviations}

AA: Amino acids; ADC: Apparent digestibility coefficients; Al: Atherogenicity index; BW: Body weight; C: cis; CF: Coefficient of fatness; CP: Crude protein; CY: Carcass yield; DHA: Docosahexaenoic acid; DM: Dry matter; DMI: Dry matter intake; DPA: Docosapentaenoic acid; EAA: Essential amino acids; EE: Ether extract; EPA: Eicosapentaenoic acid; FA: Fatty acids; FAME: Fatty acid methyl esters; FBW: Final body weight; FCR: Feed conversion ratio; FM: Fish meal; FR: Feeding rate; GE: Gross energy; HI: Hermetia illucens;

HSI: Hepatosomatic index; IBW: Initial body weight; K: Fulton's condition factor; MUFA: Monounsaturated fatty acids; PAPs: Processed animal proteins; PER: Protein efficiency ratio; PUFA: Polyunsaturated fatty acids; SBM: Soybean meal; SEM: Standard error of the mean; SFA: Saturated fatty acids;

SGR: Specific growth rate; $t$ : trans; TFA: Total fatty acids; TI: Thrombogenicity index; VSI: Viscerosomatic index; WG: Weight gain; WW: wet weight

\section{Acknowledgments}

The authors gratefully acknowledge Dr. Paolo Montersino, Mr. Dario Sola, Mr. Mario Colombano and Mrs. Alessandra Sereno for technical support, and Hermetia Deutschland GmbH \& Co. KG for the provision of the HI larvae meal.

\section{Funding}

Financial support for this work was provided by the University of Turin (ex 60\%) grant (Es. fin. 2015-2016).

\section{Availability of data and materials \\ The datasets analyzed in the current study are available from the corresponding author on reasonable request.}

\section{Authors' contributions \\ $L G, M R, I Z, A S, M P$ and FG conceived and designed the experiment. LG, SD, MDM and FG prepare the diets, performed the trial and collected the experiments data. $V M$ carried out the proximate analyses. $A B$ carried out the chitin and AA analyses. CL carried out the FA analyses. MTC, IB and EB performed the morphometric investigations. MR performed the statistical analysis. LG, MR, FG, AS, SD, AB and IZ analysed and interpret the data. LG, $M R, C L, A S, F G$ and $S D$ wrote the first draft of the manuscript. All authors critically reviewed the manuscript for intellectual content and gave final approval for the version to be published.}

\section{Competing interests}

The authors declare that they have no competing interests.

\section{Consent for publication}

Not applicable.

\section{Ethics approval and consent to participate}

The trial was designed according to the guidelines of the current European Directive (2010/63/EU) on the care and protection of animals used for scientific purposes.

\section{Author details}

'Department of Agricultural, Forest and Food Sciences, University of Torino, Largo P. Braccini 2, 10095 Grugliasco, TO, Italy. ${ }^{2}$ Department of Veterinary Sciences, University of Torino, Largo P. Braccini 2, 10095 Grugliasco, TO, Italy. ${ }_{3}^{3}$ Institute of Science of Food Production, National Research Council, Largo P. Braccini 2, 10095 Grugliasco, TO, Italy. ${ }^{4}$ Veterinary Medical Research Institute for Piedmont, Liguria and Aosta Valley, Via Bologna 148, 10154 Torino, Italy.

Received: 15 December 2016 Accepted: 15 June 2017

Published online: 01 July 2017

\section{References}

1. Publishing Group in FAO's Office for Corporate Communication. FAO (Food and Agriculture Organization of the United Nations). The State of World Fisheries and Aquaculture. Rome; 2016. pp. 204. (also available at http://www.fao.org/3/a-i5555e.pdf).

2. Gai F, Gasco L, Daprà F, Palmegiano GB, Sicuro B. Enzymatic and histological evaluations of gut and liver in rainbow trout, Oncorhynchus mykiss, fed with rice protein concentrate based diets. J World Aquacult Soc. 2012;43:218-29. 
3. Oliva-Teles A, Enes P, Peres H. Replacing fishmeal and fish oil in industrial aquafeeds for carnivorous fish. In: Davis DA, editor. Feed and feeding practice in aquaculture. Cambridge: Woodhead Publishing; 2015. p. 203-33.

4. Bureau DP. Rendered products in fish aquaculture feeds. In: Meeker DL, editor. Essential rendering. Alexandria: National Renderers Association; 2006. p. 179-84.

5. De Marco M, Martínez S, Hernandez F, Madrid J, Gai F, Rotolo L, et al. Nutritional value of two insect meals (Tenebrio molitor and Hermetia illucens) for broiler chickens: apparent nutrient digestibility, apparent ileal amino acid digestibility and apparent metabolizable energy. Anim Feed Sci Technol. 2015;209:211-8.

6. Henry M, Gasco L, Piccolo G, Fountoulaki E. Review on the use of insects in the diet of farmed fish: past and future. Anim Feed Sci Technol. 2015;203:1-22.

7. Schiavone A, Cullere M, De Marco M, Meneguz M, Biasato I, Bergagna S, et al. Partial or total replacement of soybean oil by black soldier fly larvae (Hermetia illucens L.) fat in broiler diets: effect on growth performances, feed-choice, blood traits, carcass characteristics and meat quality. Ital J Anim Sci. 2016;16:93-100.

8. St-Hilaire S, Sheppard C, Tomberlin JK, Irving S, Newton L, McGuire MA, et al. Fly prepupae as a feedstuff for rainbow trout, Oncorhynchus mykiss. J World Aquacult Soc. 2007;38:59-67.

9. Sealey WM, Gaylord TG, Barrows FT, Tomberlin JK, McGuire MA, Ross C, et al. Sensory analysis of rainbow trout, Oncorhynchus mykiss, fed enriched black soldier fly prepupae, Hermetia illucens. J World Aquacult Soc. 2011;42:34-45.

10. Roncarati A, Gasco L, Parisi G, Terova G. Growth performance of common catfish (Ameiurus melas Raf.) fingerlings fed mealworm (Tenebrio molitor) diet. J Insects Food Feed. 2015;1:233-40.

11. Gasco L, Henry M, Piccolo G, Marono S, Gai F, Renna M, et al. Tenebrio molitor meal in diets for European sea bass (Dicentrarchus labrax L.) juveniles: growth performance, whole body composition and in vivo apparent digestibility. Anim Feed Sci Technol. 2016;220:34-45.

12. Lock ER, Arsiwalla T, Waagbo R. Insect larvae meal as an alternative source of nutrients in the diet of Atlantic salmon (Salmo salar) postsmolt. Aquac Nutr. 2016;22:1202-13.

13. Piccolo G, Marono S, Bovera F, Gasco L, Parisi G, Loponte R, et al. Effect of Tenebrio molitor larvae meal on growth performance, nutrients digestibility and post mortem traits of gilthead sea bream (Sparus aurata). Anim Feed Sci Technol. 2017;226:12-20.

14. Borgogno M, Dinnella C, laconisi V, Fusi R, Scarpaleggia C, Schiavone A, et al. Inclusion of Hermetia illucens larvae meal on rainbow trout (Oncorhynchus mykiss) feed: effect on sensory profile according to static and dynamic evaluations. J Sci Food Agric. 2017. in press. doi: 10.1002/jsfa.8191.

15. Mancuso T, Baldi L, Gasco L. An empirical study on consumer acceptance of farmed fish fed on insect meals: the Italian case. Aquacult Int. 2016;24(5):1489-507.

16. ABN AMRO. Insectenkweek: kleine sector, grotekansen. Report December. 2016. https://insights.abnamro.nl/2016/12/insectenkweek/. Accessed 20 March 2017.

17. Li S, Ji H, Zhang B, Tian J, Zhou J, Yu H. Influence of black soldier fly (Hermetia illucens) larvae oil on growth performance, body composition, tissue fatty acid composition and lipid deposition in juvenile Jian carp (Cyprinus carpio Var. Jian). Aquaculture. 2016;465:43-52.

18. Surendra KC, Olivier R, Tomberlin JK, Jha R, Khanal SK. Bioconversion of organic wastes into biodiesel and animal feed via insect farming. Renew Energy. 2016;98:197-202.

19. Kroeckel S, Harjes AGE, Roth I, Katz H, Wuertz S, Susenbeth A, et al. When a turbot catches a fly: evaluation of a pre-pupae meal of the black soldier fly (Hermetia illucens) as fishmeal substitute - growth performance and chitin degradation in juvenile turbot (Psetta maxima). Aquaculture. 2012;364-365:345-52.

20. Newton L, Sheppard C, Watson W, Burtle G, Dove R. Using the black soldier fly, Hermetia illucens, as a value-added tool for the management of swine manure. In: Univ. of Georgia, College of Agric. \& environ. Sci., dept. of Anim. \& dairy Sci. Annual report; 2005.

21. Swatson HK, Gous R, lji PA, Zarrinkalam R. Effect of dietary protein level, amino acid balance, and feeding level on growth, gastrointestinal tract, and mucosal structure of the small intestine in broiler chickens. Anim Res. 2002;51:501-15.

22. Laudadio V, Passantino L, Perillo A, Lopresti G, Passantino A, Khan RU, et al. Productive performance and histological features of intestinal mucosa of broiler chickens fed different dietary protein levels. Poult Sci. 2012;91:265-70.

23. Gu X, Li D. Effect of dietary crude protein level on villous morphology, immune status, and histochemistry parameters of digestive tract in weaning piglets. Anim Feed Sci Technol. 2004;114:113-26.

24. lyeghe-Erakpotobor GT, Olorunju SAS, Oyedipe EO. Effect of protein level and flushing method on the reproductive performance of rabbits. Anim Sci J. 2005;76:209-15.
25. Daprà F, Geurden I, Corraze G, Bazin D, Zambonino-Infante JL, FontagnéDicharry S. Physiological and molecular responses to dietary phospholipids vary between fry and early juvenile stages of rainbow trout (Oncorhynchus mykiss). Aquaculture. 2011;319:377-84.

26. AOAC International. Official methods of analysis of AOAC International. 16th ed. Gaithersburg: Association of Official Analytical Chemists; 2000.

27. AOAC International. Official methods of analysis of AOAC International. 17th ed. Gaithersburg: Association of Official Analytical Chemists; 2003.

28. Wang X, Chen X, Chen L, Wang B, Peng C, He C, et al. Optimizing highperformance liquid chromatography method for quantification of glucosamine using 6-aminoquinolyl-N-hydroxisuccinimidyl carbamate derivation in rat plasma: application to a pharmacokinetic study. Biomed Chromatogr. 2008;22:1265-71.

29. Madrid J, Martínez S, López C, Orengo J, López MJ, Hernández F. Effects of low protein diets on growth performance, carcass traits and ammonia emission of barrows and gilts. Anim Prod Sci. 2013;53:146-53.

30. Schmid A, Collomb M, Hadorn R. Fatty acid composition of Swiss cooked sausages. Fleischwirtschaft. 2009;89:101-4.

31. Renna M, Gasmi-Boubaker A, Lussiana C, Battaglini LM, Belfayez K, Fortina R. Fatty acid composition of the seed oils of selected Vicia L. taxa from Tunisia. Ital J Anim Sci. 2014;13:308-16.

32. Palmegiano GB, Daprà F, Forneris G, Gai F, Gasco L, Guo K, et al. Rice protein concentrate meal as a potential ingredient in practical diets for rainbow trout (Oncorhynchus mykiss). Aquaculture. 2006;258:357-67.

33. CIE (CommissionInternationale de l'Éclairage). Recommendations on uniform colour spaces-colour difference equations, psychometric colour terms (supplement no. 2 to CIE publication no. 15). Paris: Commission Internationale de l'Éclairage; 1976.

34. Belforti M, Gai F, Lussiana C, Renna M, Malfatto V, Rotolo L, et al. Tenebrio molitor Meal in rainbow trout (Oncorhynchus mykiss) diets: effects on animal performance, nutrient digestibility and chemical composition of fillets. Ital J Anim Sci. 2015;14:670-5.

35. Renna M, Cornale P, Lussiana C, Malfatto V, Fortina R, Mimosi A, et al. Use of Pisum sativum (L.) as alternative protein resource in diets for dairy sheep: effects on milk yield, gross composition and fatty acid profile. Small Rumin Res. 2012:102:142-50.

36. FEEDIPEDIA. Feedipedia: an on-line encyclopedia of animal feeds; 2017. http://www.feedipedia.org/ Accessed 17 Feb 2017.

37. Gai F, Peiretti PG, Brugiapaglia A, Gasco L. Effects of dietary protein source and feeding regime on growth performance, nutrient digestibility, fatty acids, and quality characteristics of rainbow trout (Oncorhynchus mykiss) fillets. J World AquacultSoc. 2016:47:496-507.

38. Belluco S, Losasso C, Maggioletti M, Alonzi CC, Paoletti MG, Ricci A. Edible insect in a food safety and nutritional perspective: a critical review. Compr Rev Food Sci Food Saf. 2013;12:296-313.

39. Marono S, Piccolo G, Laponte R, Di Meo C, Attia YA, Nizza A, et al. In vitro crude protein digestibility of Tenebrio molitor and Hermetia illucens insect meals and its correlation with chemical composition traits. Ital J Anim Sci. 2015;14:338-43.

40. Muzzarelli RAA. Chitin. Oxford: Pergamon Press; 1977.

41. Stamer A, Wesselss S, Neidigk R, Hoerstgen-Schwark G. Black soldier fly (Hermetia illucens) larvae-meal as an example for a new feed ingredients' class in aquaculture diets. In: Rahmann G, Aksoy U, editors. Proceedings of the 4th ISOFAR scientific conference, "building organic bridges" at the organic world congress, 13-15 Oct., Istanbul, Turkey; 2014. p. 1043-6.

42. Muddasir J, Imtiaz A. Length weight relationship and condition factor of snow trout, Schizothorax plagiostomus (Heckel, 1838) from Lidder River. Kashmir Int J Fish Aquat Stud. 2016:4(2):131-6.

43. de Francesco M, Parisi G, Médale F, Lupi P, Kaushik SJ, Poli BM. Effect of long-term feeding with a plant protein mixture based diet on growth and body/fillet quality traits of large rainbow trout (Oncorhynchus mykiss). Aquaculture. 2004;236:413-29.

44. Dernekbaşı S. Digestibility and liver fatty acid composition of rainbow trout (Oncorhynchus mykiss) fed by graded levels of canola oil. Turk J Fish Aquat Sci. 2012;12:105-13.

45. Brinker A, Reiter R. Fish meal replacement by plant protein substitution and guar gum addition in trout feed, part l: effects on feed utilization and fish quality. Aquaculture. 2011;310:350-60.

46. Suárez MD, García-Gallego M, Trenzado CE, Guil-Guerrero JL, Furné M, Domezain A, et al. Influence of dietary lipids and culture density on rainbow 
trout (Oncorhynchus mykiss) flesh composition and quality parameter. Aquac Eng. 2014;63:16-24.

47. Marty-Mahe P, Loisel P, Fauconneau B, Haffray P, Brossard D, Davenel A. Quality traits of brown trout (Salmo trutta) cutlets described by automated color image analysis. Aquaculture. 2004;232:225-40.

48. Pieterse E, Pretorius Q, Hoffman LC, Drew DW. The carcass quality, meat quality and sensory characteristics of broilers raised on diets containing either Musca domestica larvae meal, fish meal or soya bean meal as the main protein source. Anim Prod Sci. 2014;54:622-8.

49. Figueiredo-Silva AC, Kaushik S, Terrier F, Schrama JW, Medale F, Geurden I. Link between lipid metabolism and voluntary food intake in rainbow trout fed coconut oil rich in medium-chain TAG. Br J Nutr. 2012;107:1714-25.

50. Biasato I, De Marco M, Rotolo L, Renna M, Lussiana C, Dabbou S, et al. Effects of dietary Tenebrio molitor meal inclusion in free-range chickens. J Anim Physiol Anim Nutr. 2016:100:1104-12.

51. Baurhoo B, Phillip L, Ruiz-Feria CA. Effects of purified lignin and mannan oligosaccharides on intestinal integrity and microbial populations in the ceca and litter of broiler chickens. Poult Sci. 2007;86:1070-8.

52. Tufarelli V, Desantis S, Zizza S, Laudadio V. Performance, gut morphology, and carcass characteristics of fattening rabbits as affected by particle size of pelleted diets. Arch Anim Nutr. 2010;64:373-82.

\section{Submit your next manuscript to BioMed Central} and we will help you at every step:

- We accept pre-submission inquiries

- Our selector tool helps you to find the most relevant journal

- We provide round the clock customer support

- Convenient online submission

- Thorough peer review

- Inclusion in PubMed and all major indexing services

- Maximum visibility for your research

Submit your manuscript at www.biomedcentral.com/submit 